\title{
Attracting women into male-dominated trades: Views of young women in Australia
}

\author{
Karen Struthers ${ }^{\star 1}$, Glenda Strachan ${ }^{2}$ \\ ${ }^{1}$ School of Human Services and Social Work, Griffith University, 4122 Logan, Australia \\ ${ }^{2}$ Department of Employment Relations and Human Resources Griffith University, 4122 Bris- \\ bane, Australia.
}

Received: 30.11.2018; Accepted: 21.01.2019; Published: 30.04.2019

\begin{abstract}
Context: The persistent low female participation in male-dominated trades and VET courses is not attracting a high level of public attention and policy action. There are determined, albeit ad hoc actions by advocates to raise awareness of the economic and social benefits that can result from increased female participation in the male-dominated trades. Despite these efforts gender segregation of the trades remains resistant to change.

Approach: To better understand the barriers limiting female participation in the male-dominated trades from the perspective of young women, this $\mathrm{PhD}$ study features interviews with female secondary students in four secondary schools in Queensland, Australia, and interviews with VET, school and industry stakeholders. The three primary research questions are: 1) What is the extent of gender segregation in VET and typically male-dominated trades in Australia, and how does this compare internationally? 2) Why do very few female students choose male-dominated trades as their job pathway? 3) What can be done, particularly in the education and training sectors, to increase female interest in, and take-up of, the male-dominated trades?
\end{abstract}

Findings: The results of this research showed that the composition of trade-qualified females in male-dominated trades is persistently low at $2-3 \%$. The views of young women affirmed the evidence showing system-wide barriers limit female interest in male-dominated VET trade courses and trade careers. Most influential is that gender stereotypes of work are

*Corresponding author: k.struthers@griffith.edu.au

ISSN: 2197-8646

http://www.ijrvet.net

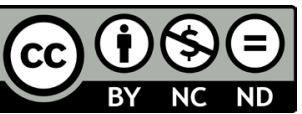


set by Year 10 and that female enrolment in Maths (a pre-requisite for male-dominated careers) is low; these trades are seen as "jobs for the boys who don't do academic," and the fear of intimidation and harassment deters young women. Low enrolment of female students in male-dominated VET trade courses indicates that this entrenched occupational segregation of the trades will remain resistant to change for some time to come.

Conclusion: The findings indicate that ad hoc responses to overcome gender segregation of the trades is not effective. Influenced by systems theory and a social ecological model (SEM) of change, the researchers promote the need for sustained, nation-wide awareness and action involving VET and school sectors, industry, government and trade unions to attract more women into male-dominated trades.

Keywords: Vocational education and training, non-traditional occupations, women in trades, VET

\section{Introduction}

The construction, electro-technology, manufacturing and auto and related trades in many advanced industrial nations are dominated by trade-qualified men. Despite the determined efforts of feminist advocates, researchers and unionists, the gender composition of maledominated trades is resistant to change, and this is an international phenomena. It can be difficult to accurately measure female participation in VET and the trades in Australia as VET enrolment data and trade composition data is not routinely disaggregated or publicly reported by gender. Research effort is generally required to comprehensively analyse gender differences in this data (economicSecurity4Women, 2014; Struthers, 2016). Despite these challenges of data reporting and collection, available research and evidence shows extremely low levels of female participation in male-dominated trades in many countries, with examples being:

- $2 \%$ of qualified trade workers in male-dominated trades in Australia are women (Australian Bureau of Statistics, 2014; Struthers, 2016).

- $4.5 \%$ of skilled trade workers in Canada are women (Statistics Canada cited Smith, J, 2017, p.1).

- Young women (25 years and under) account for only $1 \%$ of those working in the construction sector in Europe (Liebus, 2016). 
- In India it is estimated that up to 30 per cent of construction workers are women, yet they are predominantly unskilled workers or head-load carriers - women comprise $1.4 \%$ of technical officers (Patel \& Pitroda, 2016, pp.17-19).

- $3 \%$ of electricians and $2.1 \%$ of carpenters are women in the US (US Census Bureau cited in Toppin, 2018, p.70).

This is consistent with international trends (Blau, Brummond, \& Yung-Hsu Liu, 2013; International Labour Organisation, 2016). The available evidence shows that the main pipeline to male-dominated trade apprenticeships and traineeships - that is, VET courses-are overwhelmingly male (NCVER, 2014; 2015). VET in Schools (VETiS which is nationally accredited VET programs that enable students to complete their secondary school certificates) also features significant gender inequalities. The gender gap in enrolments in VETiS programs in Australia has been increasing over the past 10 years, with 17000 more male students enrolled than female students (Misko, Korbel \& Blomberg 2017, p.24). While the great majority of VETiS students do not end up in trade occupations, of those who do, males are over six times more likely than females to enter the trades (Misko, Korbel \& Bloomberg, 2017, p.11).

There is concern about the low status, relatively low enrolments and completions and lack of understanding of trades and VET generally in Australia (Dommers., Myconos., Swain., Yung, \& Clarke, 2017). Young people are often encouraged to aspire to the perceived higher status career pathways that a University education is seen as providing (Sikora \& Pokropek, 2012; Gore et al., 2017). Misconceptions and low status of VET and the trades, low and declining enrolments are also reported to be growing in European nations (Bridgford, 2016; Hoffman \& Schwartz, 2015). It is reported that in Switzerland, Germany, Austria, Denmark and Norway upper secondary school student participation in VET systems is declining from internationally high benchmarks of between 30 and 70 percent of students (Hoffman \& Schwartz, 2015, p.18).

Male-dominated trades are generally higher paid than the female-dominated trades and can offer opportunities for enhanced economic security for women (Struthers, 2016). Women are breaking through the 'glass ceiling' in pursuit of male-dominated professional courses and careers in areas such as law, medicine, accounting, and management roles (Blau et al., 2013; Workplace Gender Equality Agency, 2018), but no similar progress exists in the blue-collar occupations including, trades (Blau et al., 2013). Evidence continues to reveal that deeply embedded gender stereotypes and cultural, industrial and economic barriers inhibit the entry of women into male-dominated VET courses that lead to trade qualifications (economicSecurity4Women, 2014; Human Rights Commission, 2013; Trade Union Congress, 2013). Fundamentally unless young women themselves see low female participation in male-dominated trades as a problem, little is likely to change. Ground-breaking research on apprenticeships in the UK over a decade ago showed that strategies to counter barriers to 
non-traditional apprenticeships had largely failed and as young people show little concern about the segregation of trades (Fuller, Beck \& Unwin, 2005).

\subsection{Purpose of the Research}

This research explores the barriers that limit female participation in the male-dominated trades - with a focus on the views of young women. The aim is to formulate strategies that can be enduring and effective in increasing female participation in male-dominated VET trade courses and trade careers. This paper draws selectively from the research findings to promote strategies that target the VET system.

\subsection{Research Questions}

This research, including the literature review addressed the following questions:

1. What is the extent of gender segregation in vocational education and training (VET) and typically male-dominated trades in Australia, and how does this compare internationally?

2. Why do very few female students choose male-dominated trades as their job pathway?

3. What can be done, particularly in the education and training sectors, to increase female interest in, and take-up of, the male-dominated trades?

\section{Why Increased Female Interest and Participation in the Male-dominated Trades Matters?}

Gender segregation of the trades matters to industry, the economy and women. Low female workforce participation rates, and the segregation of women into existing female-dominated industries contributes to labour market rigidity, suboptimal productivity, and economic inefficiency due to the lack of utilisation of the skills of women (Human Rights Commission, 2013; Toohey, Boak \& Borkin, 2014), and increased labour costs due to skills shortages (Minerals Council of Australia, 2013). The benefits that could accrue from increased representation of women in male-dominated industries are stated by Toohey et al., (2014) as:

Accessing the talent of highly educated and skilled labour already resident in Australia should help lift aggregate productivity, contain wage growth, assist in lowering the future strains on the pension system and importantly help engender a more diverseworkplace and a fairer society (p. 9). 
Similarly in advocating for more women and less discrimination in the European construction industry, Liebus (2016) stated that: “...promoting gender equality is not only a driver for economic growth but also a fundamental value of the European Union” (p.1). In developing and advocating A European Quality Framework for Apprenticeships, the Confederate Syndicat European Trade Union and Union Learn with the TUC (Bridgford, 2016) recommended that the framework feature equal opportunities for all in recognition of the under-representation of women and ethnic minorities in male-dominated trades. This union/ industry alliance reported on the challenges that result from declining apprenticeship numbers across Europe and under-representation of young women and young people from ethnic minorities.

Skills shortages are evident or are projected in many trade areas in Australia and overseas. Attracting and retaining underutilised sources of talent, including women, are recognised strategies to address skills shortages (Minerals Council of Australia, 2013; Toohey et al., 2014). In asking who is going to build the 'Trump' wall given construction skills shortages in the US, Toppin (2018, p.73) argued that trades and trade training need to be viewed not as "menial, but meaningful" to increase the supply of building trade workers - particularly more women and people of non-Anglo cultures.To enhance the economic opportunities for young women, improved access to education, higher remuneration for feminised work, and pathways into higher paid male-dominated occupations, including trades, are all worthy of attention. The experience of young women is that far too many exist on the fringes of the labour market where they are underemployed, in low paid, or insecure work (ILO, 2016). The focus on the views of young people in this is research is guided by evidence indicating that interventions that actively inform and engage young people as agents of change not simply targets for change can be effective (United Nations Development Program, [UNDP, 2018). Elevating awareness of the male-dominated trades among young women and translating the findings of this research into strategies for the VET sector, schools, industry and government was a priority of this research from the outset.

\section{Theoretical Framework}

In acknowledging that inequality in the labour force is primarily a function of the unequal access to capital, and resources and other oppressive forces that are at the foundation of all communities (Acker, 2011; Walby, 1986), feminist scholars argue that gender-based occupational segregation is a product of the long-standing impact of male-dominated culture and organisations; the dual role for women as workers and primary carers, the lack of affordable child care and choice that many women experience (Adkins, 1994; Walby, 1986). The persistent division of work along gender lines continues to be reinforced in the labour market, education and training sectors by the pervasive influence of gender role stereotyping in popular media and culture (Gadassi \& Gati, 2009; Sikora \& Pokropek, 2012; Smith, S.L., Choueiti., 
Prescott., \& Pieper, 2012). Gender essentialist views, which see women as being innately more competent than men in services, nurturance and social interaction, and men as being more adept at problem-solving, analytical skills and complex abstract reasoning than women (Charles \& Grusky, 2004) are embedded in Western culture. This serves to deter women from careers in the male-dominated trades. The influence of gender has been considered influential in the career aspirations and pathways of young people with gender differences in subject and career choice forming by year 10 among secondary school students (Rogers \& Creed, 2011; Sikora \& Pokropek, 2012). Gender stereotypes continue to have a profound influence on the confidence and the self-efficacy young people have in relation to careers and the pursuit of Maths. Maths is considered a pre-requisite for non-traditional careers, yet fewer female students than males pursue to a high level in school (Gore et al., 2017; Sikora \& Pokropek, 2012).

International and Australian studies have reported that career options presented to female students are narrow and discourage the pursuit of non-traditional subject and occupational choices (Fuller et al., 2005; International Labour Organization, 2009; Shewring, 2009). In Australia there has been substantial public attention and policy action to promote science, technology, maths and engineering for both boys and girls. Maths and science are prerequisite subjects for entry into male-dominated trades courses. In Australia it is reported that: "Despite numerous government-led initiatives to balance gendered participation in the STEM workforce, the gender disparity has remained a persistent trend over many years" (Spearman \& Watt, 2013, p.125). It is recognised that children develop a gender schema of appropriate masculine and feminine behaviours that they learn and that if girls valued and were encouraged in to male-dominated STEM subjects and careers at an early age, "...their self-efficacy for these subjects will improve" (Spearman \& Watt, 2013, p.178).

Systems theory (Friedman \& Allen, 2011) is applied in this research as an organising framework to analyse the structural and individual level factors that interact and serve as barriers that limit female participation in the trades. Within a systems approach, the Social Ecological Model (SEM) (UNICEF, 2015) provides five levels to target -individual, interpersonal, community, organisational and policy/enabling environment-to identify and analyse the multi-level factors that contribute to public issues. As a systems approach, SEM (UNICEF, 2015) provides the framework for the discussion and action arising from this research.

\section{Making the Case for Change}

The need to tackle gender-segregation of the trades has been raised over many years (Shewring, 2009; Human Rights Commission, 2013; economicSecurity4Women, 2014; Wright \& Conley, 2018). It has not yet captured the sustained, high level attention that "troublesome" issues attract. Agenda-building theory Cobb and Elder (cited in Maddaleno \& Beinhauer, 2005) explains how public interest in issues can be generated, particularly through evidence 
and media, to mount pressure and elicit action from decision-makers. Social problems attract public action and policy change when they are considered "troublesome and in need of repair" (Loseke, 2003, p.14 cited in Wanna., Butcher., \& Freyens, 2010, p.64). To be successful in "claims-making" on decision makers-activists must be persistent, provide evidence that a social problem exists, and evidence that economic benefits that can be derived from addressing it (Loseke, 2003, cited in Wanna, et al., 2010, p. 64). To date action has been wideranging but not sustained and organised. Diversity management in industry tends to be relied upon as a panacea to reduce occupational segregation. The critical diversity management studies claim that it can be driven more by business-led than equity or social justice goals and that it has limited capacity to tackle occupational segregation (Healy, 2015; Knights \& Omanovic, 2016; Sharp., Franzway., Mills, \& Gill, 2012; Strachan., French \& Burgess, 2010). This research is motivated by a desire to strengthen the claim that the removal of structural barriers contributing to gender segregation of the trades requires renewed, high-level action and collaboration among VET, school, industry, trade union and government sectors.

\section{$4 \quad$ Research Design and Methods}

This article focusses on two areas of inquiry from the research: (1) the quantitative data collection to determine the extent of gender segregation of the trades and VET courses and (2) the qualitative data is selectively analysed to draw out the issues most relevant to the VET sector.

\section{Quantitative Data Collection: Women in male-dominated trades in Australia}

In order to determine the extent of gender segregation of the trades in Australia the Australian Bureau of Statistics (ABS) labour force trade composition data from 1994 to 2014, and the National Centre for Vocational Education Research (NCVER) vocational education course data sets were analysed. As both sources of data do not routinely disaggregate the enrolment and completion data by qualities such as gender or cultural background, the gender data reporting was manually extracted. The male-dominated electro-technology, automotive, mining, manufacturing and construction industries were selected for analysis. This lack of detailed and routine gender disaggregation of trades and trade course data is in itself problematic. It serves to mask, rather than expose the inequality.

\section{Qualitative Data Collection}

Focus group interviews of one hour duration were conducted with 68 secondary students aged 15-18 years at four schools in geographically disperse, but primarily working class areas of Queensland, Australia in 2013 and 2014. Female and male students were invited by staff, 
but only four boys in total participated. To complement and give context to the views of students, seventeen staff were also interviewed individually or in small groups at these schools. In addition, eleven career advisers, vocational educators and industry representatives from a number of regions across Australia were interviewed to provide their views on barriers and opportunities to the take-up of male-dominated trades by women. Ethics clearance was granted by Griffith University on November 11, 2013 (GU ref No./35/13HREC)

The specific questions in the interview schedules canvassed the views of participants on why so few female students pursue male-dominated trade courses and careers; how female students perceive the trades; whether the low female participation is a concern for them, and what action, if any, can be taken to increase female entry into male -dominated trades. This narrative data was subject to thematic analysis to identify both common and disparate themes. Four themes are selected from the qualitative analysis for discussion in this article. They are selected on the basis that they capture factors that both contribute to, and can overcome, low female participation in male-dominated trades and they are relevant to the VET sector.

\section{$5 \quad$ Research Findings}

\section{Quantitative Data - Persistent Low Female Participation}

The results of the data analysis show the pattern of low female participation in the maledominated trades has been consistent over the past two decades at $2 \%$ or less, with little sign that increasing numbers of women are in the supply pipeline to these trades.

Table 1: Females Employed in Selected Trade Occupations: Australia, 1994-2014

\begin{tabular}{|l|l|l|l|l|l|l|}
\hline \multicolumn{2}{|l|}{1994} & \multicolumn{2}{l|}{$\mathbf{2 0 0 4}$} & \multicolumn{2}{l|}{$\mathbf{2 0 1 4}$} \\
\hline Occupation & $\begin{array}{l}\text { No. of } \\
\text { females }\end{array}$ & $\begin{array}{l}\text { \% of total } \\
\text { employed } \\
\text { persons }\end{array}$ & $\begin{array}{l}\text { No. of } \\
\text { females }\end{array}$ & $\begin{array}{l}\text { \% of total } \\
\text { employed } \\
\text { persons }\end{array}$ & $\begin{array}{l}\text { No. of } \\
\text { females }\end{array}$ & $\begin{array}{l}\text { \% of total } \\
\text { employed } \\
\text { persons }\end{array}$ \\
\hline $\begin{array}{l}\text { Automotive and } \\
\text { Engineering Trade } \\
\text { Workers }\end{array}$ & 3,455 & $(1.1)$ & 4,055 & $(1.3)$ & 2,069 & $(0.6)$ \\
\hline $\begin{array}{l}\text { Construction Trade } \\
\text { Workers }\end{array}$ & 2,380 & $(1.7)$ & 1,665 & $(0.9)$ & 1,529 & $(0.7)$ \\
\hline $\begin{array}{l}\text { Electro-technology, } \\
\text { Telecommunications } \\
\text { Trade Workers }\end{array}$ & 2,200 & $(1.6)$ & 2,673 & $(1.8)$ & 3,766 & $(1.8)$ \\
\hline
\end{tabular}


Source: Extracted from Australian Bureau of Statistics Employed persons (STE08) by Occupation (ANZCO occupation) and Sex, August 1991 onwards. Labour Force, Australia, Detailed, Quarterly, Feb 2014. (Series 6291.0.55.003). Retrieved on September 4, 2014. http:// www.abs.gov.au/AUSSTATS/abs@.nsf/DetailsPage/6291.0.55.003Feb\%202014?OpenDocument (cited Struthers, 2017). Note: Percentages are not included in the source table. They were calculated from the total employed persons. I take responsibility that the information obtained from ABS SuperTABLES is appropriate for its intended use.

The actual number of female trade workers in 1994 in automotive and engineering $(3,455)$ and construction $(2,380)$ was higher than those in 2014 (2,069 and 1,529 respectively). The data analysis of vocational courses indicates that the pipeline for females to the trades is severely blocked. The manual disaggregation by gender of National Centre for Vocational Education Research (NCVER, 2014) data for the period 2000-2014 showed that the number of female students enrolled in school-based and post-school male-dominated trade courses is very low. The school-based manufacturing and automotive courses showed higher enrolments of females (13\% and $6.8 \%$ respectively) than other courses, and some growth since 2006.

Table 2: Apprentices and Trainees within Selected Major Industry Skills Councils: Australia, 2004-2014

\begin{tabular}{|c|c|c|c|c|c|c|}
\hline \multirow[t]{2}{*}{$\begin{array}{l}\text { Major Skills } \\
\text { Council }\end{array}$} & \multicolumn{3}{|c|}{2004} & \multicolumn{3}{|c|}{2014} \\
\hline & $\begin{array}{l}\text { No. of } \\
\text { males }\end{array}$ & $\begin{array}{l}\text { No. of } \\
\text { females }\end{array}$ & $\%$ females & $\begin{array}{l}\text { No. of } \\
\text { males }\end{array}$ & $\begin{array}{l}\text { No. of } \\
\text { females }\end{array}$ & $\%$ females \\
\hline $\begin{array}{l}\text { Construction } \\
\text { and Property } \\
\text { Services }\end{array}$ & 45,368 & 7,607 & 14.36 & 64,382 & 4,275 & 6.2 \\
\hline E-Oz Energy & 22,417 & 264 & 1.2 & 43,393 & 972 & 2.2 \\
\hline Manufacturing & 41,128 & 3,909 & 8.6 & 58,543 & 5,884 & 9.1 \\
\hline $\begin{array}{l}\text { Auto Skills } \\
\text { Australia }\end{array}$ & 39,787 & 1,699 & 4.1 & 38,981 & 1,986 & 4.8 \\
\hline $\begin{array}{l}\text { Community } \\
\text { Services and } \\
\text { Health }\end{array}$ & 3,213 & 21,233 & 86 & 4,805 & 38,429 & 88 \\
\hline
\end{tabular}


Source: Extracted from NCVER Apprentices and Trainees Collection, March 2014. Retrieved September 6, 2014 from VOCSTATS via registered log-in (cited Struthers, 2016). https:// www.ncver.edu.au/wps/portal/vetdataportal/data/menu/vocstats. Source table did not include percentages. These have been calculated manually. Note: Administrative collection on apprentices and trainees. Sourced by NCVER from state training authorities via Australian Apprenticeship Centres. I take responsibility that the information obtained from VOCSTATS is appropriate for its intended use.

\section{Qualitative Data _ “we feel intimidated."}

Most of the young women in this research indicated that they would feel intimidated in mostly male trade courses. Very few said they or their peers intend to pursue VET courses or careers in male-dominated trades. The young women as well as the VET, school and industry stakeholders described a common public view that "trades are not as good as uni." They acknowledged that schools, parents and the community can discourage young women from pursuing trades by giving higher status to academic careers over VET and trades. Four major themes emerged from the interviews that showed the scale of the barriers that limit female enrolment in male-dominated VET trade courses and apprenticeships. These are discussed below:

The powerful influence of gender stereotypes on careers. The students recognised that gender stereotypes and other barriers deter female participation in trades in construction, the auto-industry, electro-technology manufacturing and other male-dominated industries. Comments like: "trades are jobs for the boys who don't do academic" were common at each school. Students raised the roles played by media, popular culture and people around them in determining what professions are mostly women's or men's work. Their comments were consistent with the literature showing that gender stereotypes significantly impact male and female students' career decision-making and limit choices (Sikora \& Pokropek, 2012; Gadassi \& Gati, 2009).

The lack of information about VET and male-dominated trade courses. Female students showed a lack of knowledge of male-dominated VET courses and trades, and few had handled trade tools. One student suggested that: "More girls would do it [male-dominated trades] if we knew more about it-if we had a lot more exposure to it to find out what it's really like." A number of students expressed interest in knowing more about the trades and having mentors. The exceptions were cases where the female students worked alongside a "tradie dad" or family member who encouraged them to use tools and undertake a trade career, giving them confidence in their trade skills and identity. The students' reported that staff at their school were generally helpful in providing career information and opportunities, but it was apparent from the limited knowledge that students had of the male-dominated trades that 
few students in the groups were seeking out external sources of information or experiences of these trades.

Intimidation and harassment. Students generally agreed that a wide range of opportunities are available to them, yet many female students said that they "cop flak" or they would feel intimidated for pursuing a male-dominated VET pathway. This was expressed in a student comment as: "Only one or two girls do it, and you feel intimidated." At each of the four secondary schools participating in this research, the number of female students enrolled in VETiS courses, such as construction, ranged from one to five out of classes that comprised up to 25 students. Another student raised the self-esteem and confidence of female students:

Girls under-estimate themselves ... It is stereotyped as a female thing to be in an office, or hairdressing ... girls don't think they can do it [the male-dominated trades]. If they walk into class full of males, they will feel intimidated.

Incongruence with female identity. For some female students the male-dominated trades were incongruent with their own feminine identity or sense of their capabilities. Some female students expressed a fear of being harassed or labelled gay if they pursue male-dominated VETiS courses. This was expressed by one student as: "If you go into those trades, you lose some of your femininity ... that's important to girls . . . you get called butch or a tomboy." Another female student expressed a more confident view of herself and the capabilities of girls, saying: "They [boys] are more scared we are going to show them up. They are already competing against each other, let alone a girl in the room." The protection of female identity and hetero-normative view of sexuality and identity was pronounced in this group with the fear of being lesbian or butch acting as a deterrent to male-dominated trades. In exploring issues for women of non-conforming sexual identity in her research, Wright (2011, p.182) exposed the intimidation and other challenges these women face being "one of the lads" in a male-dominated industry.

\section{VET, education and industry stakeholder views}

VET and school educators, career advisors and industry personnel-were also interviewed to provide contemporary context, and validation of the student views, on what programs and support is available for students to pursue non-traditional career pathways. The stakeholders acknowledged that "only a handful" of female students schools pursue male-dominate VET courses in construction, mechanics and other male-dominated trade areas. They expressed concern that parents and the community generally hold University courses and professional careers in high esteem relative to trades and VET courses. Like the students, they also said that trades continue to be seen as jobs for boys, and that girls are at risk of intimidation and harassment if they pursue a male-dominated trade. Consistent with research, several adults suggested that female students are weighing up how well they may achieve in a non-traditio- 
nal role (their self-efficacy), whether they can do it, and how it would affect their self-identity (Rogers \& Creed, 2011). Comments included:

- "Trades are seen as an under-qualification..."the exception is parents who have trade experience."

- "Trades, that's seen as being for kids who aren't academic ... but in fact you have got to be smart to do a trade" and "It's a hands-on job, doesn't mean you don't use your head."

- "Gender stereotypes are still there ... you constantly have to open their eyes, alert them to possibilities ... stereotypes are set by Year 10, and mostly girls would not even consider a trade."

- "Year 8 boys and girls are segregated straight up—boys primarily into [industrial learning technologies] and girls into [home learning technologies]."

The views of adult stakeholders affirmed the research findings (Sikora \& Pokropek, 2012) that gender stereotypes of work are set by Year 10 and that Maths is an essential subject choice for the pursuit of a male-dominated career. The significance of Science Technology Engineering Mathematics (STEM) as a prerequisite for male-dominated VET courses and trades was raised by adult stakeholders, but the students showed little understanding of this requirement. School-based educators and career advisors expressed the limited capacity they have to overcome the influence of media and popular culture in determining what are acceptable male and female behaviours, identities and career aspirations. In addition, school staff indicated that most schools have limited career advice staff and dedicated VET advisors to organise "try-a-trade" days, trade work advice and opportunities for male or female students. The staff who seek to encourage non-traditional course and career choices for students through events, industry mentors and work experience, indicated that much of their own (not paid work) time is allocated to these tasks. It was instructive to hear industry representatives cite the need for national industry strategies, early careers learning, advertising and programs that influence and excite female students and women about the possibilities male-dominated trades offer. These stakeholders were active in, or aware of the benefits of systemic strategies, with high level co-ordination and collaboration. They recommended that collaboration, with government, VET, schools and industry support was needed to generate positive change. 


\section{Discussion: Action for Change in VET and Beyond}

This research affirmed that many barriers deter female students from pursuing VET courses in male-dominates trades and trade careers. There were encouraging signs that if the young women knew more about male-dominated trades, and if they could feel less intimidated by gender stereotypes, they may well be more likely to consider pursuing VET courses and careers in male-dominated trades. While gender stereotyping of careers remains so pervasive, the pool of female students who are interested in pursuing a VET course or career in maledominated trades, will remain extremely small. The entrenched low female composition of the male-dominated trade sectors at around $2 \%$, and low numbers in the training 'pipeline', indicate that an expanded pool of female trade-qualified workers is a long way from being realised. Gender-essentialist views that distinguish careers as primarily male or female continue to act as barriers to girls having interest in careers in electro-technology, automotive, construction and other trades that are deemed typically male (Sikora \& Pokropek, 2012). There is a place for increased partnerships between the VET sector, schools and industry to inform, excite and ultimately engage more female students in school and post-school VET courses that lead to qualifications in male-dominated trades. No specific sector or organisation is assuming responsibility for action to reduce gender segregation of the male-dominated trades. No one sector, including the VET sector, will be effective acting in an adhoc, isolated manner. In drawing on agenda-building theory Cobb and Elder (cited in Maddaleno \& Beinhauer, 2005) to build momentum for change on this issue, ongoing evidence of the benefits that result from having a higher proportion of women in male-dominated trades and ongoing advocacy are needed. Expanding the pathways for girls into male-dominated trades is worthy of nation-wide attention. Priorities in a nation-wide strategies could include:

- More systemic action across industry, unions, VET and school sectors, career advice and government that is sustained and resourced (economicSecurity4Women 2014; Shewring, 2009; Struthers, 2016; Wright, 2011, 2014). This could usefully include industry and VET strategies with aspirational targets, such as increasing female participation in male-dominated VET courses and trades by ten percent in ten years.

- More gender aware education, training policies and early years career interventions that elevate the importance of STEM subjects for female students, encouraging more to pursue male-dominated occupations, including trades (National Union of Teachers, 2012; Sikora \& Poropek, 2012).

- Active promotion of equal opportunity and diversity strategies in male-dominated trade sectors that are driven by economic and social justice objectives. 
- Expansion of advertising campaigns, mentoring and school-based trade work experience that can engage young women in male-dominated trades.

- Reporting of gender disaggregated data on trade courses and apprenticeships to monitor progress (economicSecurity4Women, 2014).

The SEM model is instructive in showing the multi-sector action that is required by activists and "claims-makers" in VET, schools, unions and industry to increase female participation in the male-dominated VET courses and trades. It is adapted in this article to provide some impetus for strategy and action in and beyond the VET and school sectors.

Table 3: Women into Trades - A Multi-Sector Strategy. The Social Ecological Model as applied to gender segregation of the trades.

\begin{tabular}{|c|c|}
\hline SEM level & Areas for analysis and action \\
\hline Individual & $\begin{array}{l}\text { Provide more non-gendered career information, } \\
\text { Try-a-Trade and related experiences for female } \\
\text { students. Begin in early years of education. }\end{array}$ \\
\hline Interpersonal & $\begin{array}{l}\text { Foster more student peer support systems that } \\
\text { encourage and reward female students in male- } \\
\text { dominated VET courses. }\end{array}$ \\
\hline Community & $\begin{array}{l}\text { More VET and school partnerships that inform } \\
\text { and encourage female participation in male- } \\
\text { dominated VET trade courses. Promote positive } \\
\text { role models, positive views of VET and male- } \\
\text { dominated trades and media that is gender } \\
\text { inclusive. }\end{array}$ \\
\hline Organisational & $\begin{array}{l}\text { Establish a multi-sector national industry } \\
\text { strategy, with leadership and accountability } \\
\text { (from VET and school sectors, trade unions, } \\
\text { industry leaders and government) to promote } \\
\text { economic benefits of increased female enrolment } \\
\text { in male-dominated trade courses and } \\
\text { apprenticeships. Government to improve } \\
\text { awareness and accountability by routinely } \\
\text { collecting and reporting on gender disaggregated } \\
\text { VET enrolment and trade composition data. }\end{array}$ \\
\hline Policy/ enabling environment & $\begin{array}{l}\text { Local, state, national laws, policies and plans to } \\
\text { promote gender equality, diversity and inclusion } \\
\text { in schools, VET and trades. Consider application } \\
\text { of female enrolment targets in male-dominated } \\
\text { VET courses and trade careers; public } \\
\text { procurement policies to promote industry } \\
\text { employment of women in male-dominated trades } \\
\text { and workforce composition reporting } \\
\text { requirements (and penalties for non-compliance) } \\
\text { on industry }\end{array}$ \\
\hline
\end{tabular}


It is critical that further research continues to illuminate and elevate the issues associated with gender segregation of VET trade courses and the trade careers. It is particularly important that the perspectives and experiences of young people continue to guide policy and action. A limitation of this research is that with a relatively small sample of students, the results cannot be generalised to a wider population of young people. Youth surveys or interviews with a much larger population may be beneficial in gaining a wider, more representative, sample and in engaging more young people on the issue of low female representation in the trades.

\section{Conclusion - A Role for VET and Young People}

Importantly the VET sector can play a leadership role in elevating and responding to the challenge of increasing female participation in male-dominated trades. Ultimately little change will occur unless young women break through misconceptions of the trades and become aware that careers in male-dominated trades can be rewarding and impact positively on their economic security. The goal is for young people-from all socio-demographic, academic and cultural backgrounds and gender- to have full opportunities for economic security and job satisfaction. Collaboration between VET, industry, schools and trade unions is needed to develop targeted strategies aimed at increasing female participation in the male-dominated trades. In future young people need to be free to choose from the full range of careers, and not the gendered range that has been cultivated in books, media screens, toys, and magazines.

\section{References}

Acker, J. (2011). Theorizing gender, race, and class in organizations. in Jeanes, E., Knights, D. and Martin, P.Y. (eds) Handbook of Gender, Work, and Organization(pp 65-80). Chichester: Wiley.

Adkins, L. (1994). Gendered work sexuality, family and the labour market. Buckingham, UK: Open University Press.

Australian Bureau of Statistics (2014). Employed persons (STE08) by Occupation (ANZCO occupation) and Sex, August 1991 onwards. Labour Force, Australia, Detailed, Quarterly, Feb 2014. (Series 6291.0.55.003). Retrieved on September 4, 2014. http://www.abs.gov.au/AUSSTATS/abs@. nsf/DetailsPage/6291.0.55.003Feb\%202014?OpenDocument

Australian Bureau of Statistics. (2012) 1301.0 Year Book, 2012. Vocational Education and Training (VET). Canberra: Australia. Retrieved from http://www.abs.gov.au/ausstats/abs@.nsf/Lookup/13 01.0Main+Features1062012

Australian Bureau of Statistics. (2013b) Labour Force. Australia. Detailed Quarterly (Cat.No. 6291.0.55.003) SuperTABLE E08 _ aug.96. Canberra: Australia. Retrieved from http://www.abs. gov.au/ausstats/abs@nsf/mf/6291.0.55.003

Australian Bureau of Statistics (2014) Australian Bureau of Statistics Employed persons (STE08) by Occupation (ANZCO occupation) and Sex, August 1991 onwards. Labour Force, Australia, De- 
tailed, Quarterly, Feb 2014. (Series 6291.0.55.003). Retrieved from http://www.abs.gov.au/AUSSTATS/abs@.nsf/DetailsPage/6291.0.55.003Feb\%202014?OpenDocument

Blau, F.D., Brummond, P., \& Yung-Hsu Liu, A. (2013). Trends in occupational segregation by gender 1970-2009: Adjusting for the impact of changes in the occupational coding system. Demography, 50, 471-492. doi: 10.1007/s13524-012-0151-7

Bridgford, J. (2016). A European Quality Framework for Apprenticeships. A European Trade Union Proposal. Confederate Syndicat European Trade Union and UnionLearn with the TUC. Retrieved from https://ec.europa.eu/social/BlobServlet?docId=15575\&langId=en

Charles, M. \& Grusky, D. (2004). Occupational Ghettos. The Worldwide Segregation of Women and Men. US: Stanford University Press.

Dommers, E., Myconos, G., Swain, L., Yung, S. \& Clarke, K. (2017), Engaging young early school leavers in vocational training, National Centre for Vocational Education Research (NCVER), Adelaide.

Economic Security4Women (2014). Women and girls into non-traditional occupations and industries: Broadening career options for secondary school students [Report]. Retrieved from http://www.security4women.org.au/wp-content/uploads/eS4W-Career-Exploration-Project-Report-20140615. pdf

Friedman, B. D. \& Allen, K. (2011). Systems Theory. In Blandell, J. (Ed.). Theory and practice for clinical social work (2nd. ed., 3-21). US: Sage Publications.

Fuller, A., Beck, V., \& Unwin, L. (2005) The gendered nature of apprenticeships: Employers and young people's perspectives. Education + Training 47(4/5), 298-311. doi:10.1108/00400910510601887

Gadassi, R. \& Gati, I. (2009) The effect of gender stereotypes on explicit and implicit career preferences. The Counseling Psychologist, 37,6, 902-922. http://dx.doi.org/10.1177/0011000009334093

Gore, J., Ellis, H., Fray, L., Smith, M., Lloyd, A., Berrigan, C., Lyell, A., Weaver, N, \& Holmes, K. (2017), Choosing VET: investigating the VET aspirations of school students, NCVER, Adelaide. https:// www.ncver.edu.au/_data/assets/pdf_file/0028/1142749/Choosing-VET-investigating-the-VETaspirations-of-school-students.pdf

Healy, G. (2015) The Politics of Inequality and Diversity. History, Society and Biography. Chapter 1 Bendl, R., Bleijenbergh, I., Henttonen, E., Mills, A.J. (2015). The Oxford Handbook of Diversity in Organizations. Oxford University Press.

Hoffman, N. \& Schwartz, R. (2015). Gold Standard: The Swiss Vocational Education and Training System. Washington, DC: National Center on Education and the Economy. Retrieved from http:// ncee.org/wp-content/uploads/2015/03/SWISSVETMarch11.pdf

Human Rights Commission. (2013). Women in male-dominated industries. A tool kit of strategies. Retrieved from https://www.humanrights.gov.au/publications/women-male-dominated-industries-toolkit-strategies-2013/

International Labour Organization. (2009). Youth employment: Breaking gender barriers for young men and women. Retrieved from http://www.ilo.org/wcmsp5/groups/public/---dgreports/--gender/documents/publication/wcms_097919.pdf

International Labour Organisation. (ILO, 2016). Women at Work: Trends 2016, Retrieved from http:// www.ilo.org/gender/Informationresources/Publications/WCMS_457317/lang--de/index.htm

Knights, D. \& Omanovic, V. (2016) (Mis)managing diversity: exploring the dangers of diversity management orthodoxy. Equality, Diversity and Inclusion: An International Journal. 35, 1, 5-16, doi: 10.1108/EDI-03-2014-002 
Liebus, P. (2016, March 11). European Builders Confederation. Promoting gender equality in the construction sector. https:/www.euractiv.com/section/social-europe-jobs/opinion/diversify-theconstruction-sector-for-jobs-and-growth/

Maddaleno, M. \& Breinbauer, C. (2005). Youth: Choices and change. Washington. Pan American Health Organisation.

Minerals Council of Australia. (2013). Workforce gender diversity review white paper: It's not just a program. Retrieved from http://www.minerals.org.au/file_upload/files/resources/education_training/Gender_Diversity_Review_White_Paper(2).PDF

Misko, J., Korbel, P. \& Blomberg, D. (2017). VET in Schools students: characteristics and post-school employment and training experiences, National Centre for Vocational Education and Research (NCVER), Adelaide.

National Centre for Vocational Education Research (2014). Apprentices and Trainees Collection, March 2014. Retrieved September 6, 2014 from VOCSTATS via registered log-in https://www. ncver.edu.au/wps/portal/vetdataportal/data/menu/vocstats

National Union of Teachers. (2012). Boys' things and girls' things. Retrieved from https://www.teachers.org.uk/files/boys-things-revise-8875.pdf

Patel, R. \& Pitroda, J. (2016). The Role of Women in Construction Industry: An Indian Perspective. Indian Journal of Technical Education (IJTE)Special Issue for ICWSTCSC - 2016 pp.17-23. Retrieved from https://www.Researchgate.Net/Publication/294355586_The_Role_Of_Women_In_Construction_Industry_An_Indian_Perspective

Rogers, M. \& Creed, P. (2011). A longitudinal examination of adolescent career planning and exploration using a cognitive career theory framework. Journal of Adolescence, 34(1), 163-172. doi:10.1016/j.adolescence.2009.12.010

Sharp, R., Franzway, S., Mills, J. \& Gill, J. (2012) Flawed Policy, Failed Politics? Challenging the Sexual Politics of Managing Diversity in Engineering Organizations. Gender, Work \& Organization, 19: 555-572. doi:10.1111/j.1468-0432.2010.00545.x

Shewring, F. (2009) The female 'tradie': Challenging employment perceptions in non-traditional trades for women. National Centre for Vocational Education Research (NCVER).Retrieved from http://www.ncver.edu.au/publications/2100.html

Sikora, J., \& Pokropek, A. (2012). Gender segregation of adolescent science career plans in 50 countries. Science Education, 96(2), 234-264. doi: 10.1002/sce.20479

Smith, J. (2017). Women account for just $4.5 \%$ of skilled trade workers in Canada: report. The Canadian Press. October 25, 2017. Retrieved October 10, 2018 from https://globalnews.ca/news/3823621/ women-skilled-trades-manufacturing/

Smith, S.L., Choueiti, M., Prescott, A., \& Pieper, K. (2012). Gender roles \& occupation: A look at character attributes and job-related aspirations in film and television. Research. Geena Davis Institute on Gender in Media. Retrieved from http://www.thegeenadavisinstitute.org/

Spearman, J. \& Watt, H. M. G. (2013). Women's aspirations towards STEM careers: A motivational analysis (pp. 175-191). In W. Patton (Ed.), Conceptualising women's working lives: Moving the boundaries of discourse. Rotterdam, The Netherlands: Sense Publishers.

Strachan, G., French, E. L. \& Burgess, J. (2010). Equity and diversity within organisations: putting policy into practice. In Strachan, G, French, E. L., and Burgess, J. (Eds.) Managing Diversity in Australia: Theory and Practice. McGraw-Hill, Sydney, Australia, 57-74. 
Struthers, K. (2016). Paving the Way for Girls into Male-Dominated Trades: Reducing Gender Segregation in the Trades. Thesis (PhD Doctorate). Retrieved from https://www120.secure.griffith.edu. au/rch/items/2df7bcf1-2e0c-4a0d-a198-e845468f7c48/1/

Toohey, T., Boak, A. \& Borkin, P. (2014). Labour market recovery and progress on female participation? Australia and New Zealand Economic Analyst, 14, 6. Retrieved from https://www.wgea.gov. au/sites/default/files/Female_Participation_Update_27March2014.pdf

Toppin, I. (2018). Who is Going to Build the Wall? A Building Trades Crisis in the U.S.A. International Journal for Research in Vocational Education and Training, [S.1.], v. 5, n. 1, p. 64-76, Apr. 2018. doi:https://doi.org/10.13152/IJRVET.5.1.4.

Trade Union Congress. (TUC, 2013). Under-representation by gender and race in apprenticeships. UK. Retrieved from https://www.tuc.org.uk/sites/default/files/UnderRepresentationInApprenticeships.pdf

UNICEF (2015). Social Ecological Model. Description of Levels. p. 2 Adapted by UNICEF from the Centers for Disease Control and Prevention (CDC), The Social Ecological Model: A Framework for Prevention, http://www.cdc.gov/violenceprevention/overview/social-ecologicalmodel.html

United Nations Development Program (UNDP, 2018). Guiding Principles for Supporting Young People as Critical Agents of Change in the 2030 Agenda. Retrieved from https://www.youth4peace.info/ GuidingPrinciples/Youth2030

Walby, S. (1986). Patriarchy at work: Patriarchal and capitalist relations in employment. Cambridge: Polity Press.

Wanna, J., Butcher, J., \& Freyens, B. (2010). Policy in action: The challenge of service delivery. Sydney, Australia: University of New South Wales Press.

Workplace Gender Equality Agency. (2018). Higher education and labour market statistics. https:// www.wgea.gov.au/sites/default/files/graduate-labour-market-statistics.pdf

Wright, T. (2011). Gender and sexuality in non-traditionally female work: an intersectional analysis of the experience of women in different occupational groups in the UK construction and transport industries. (Doctoral dissertation, Queen Mary University of London). Retrieved from https:// qmro.qmul.ac.uk/jspui/bitstream/123456789/2503/1/WRIGHTGenderand2011.pdf.

Wright, T. (2014). The Women into Construction Project: An assessment of a model for increasing women's participation in construction. Centre for Research in Equality and Diversity (CRED) Queen Mary University of London. Retrieved from http://www.busman.qmul.ac.uk/research/researchcentres/cred/docs/134959.pdf

Wright, T. \& Conley, H. (2018).Advancing gender equality in the construction sector through public procurement: making effective use of responsive regulation. Economic and Industrial Democracy, Published Online March 21, 2018. https://doi.org/10.1177/0143831X17745979. 


\section{Biographical notes}

Dr Karen Struthers is a Research Fellow (casual), School of Human Services and Social Work, Griffith University, Queensland, Australia. Dr Struther's research interests focus on occupational segregation and young people as agents of change.

Professor Glenda Strachan is Professor Emeritus in the Department of Employment Relations and Human Resources Griffith University, Brisbane, Australia. Her research interests centre on contemporary and historical workplace change especially issues relating to women's working experience. The impact of organisational and national employment policies, especially EEO and diversity management, is a focus of her work and she has published widely in journals. She is co-author of Managing Diversity in Australia: Theory and Practice, published in 2010 and co-editor of Gender and the Professions: International and Comparative Perspectives, Routledge 2018. 